\title{
MASYARAKAT SIPIL DAN PENGELOLAAN ZAKAT: REPOSISI LAZ BERDASARKAN UU NOMOR 23 TAHUN 2011
}

\author{
Deni Purnama \\ (Dosen STEI SEBI)
}

\begin{abstract}
ABSTRAK
Di tengah semangat masyarakat sipil dalam memberdayakan dana zakat, muncul kemudian regulasi yang tercantum dalam Undang-Undang Nomor 23 Tahun 2011, Regulasi ini terkesan bertentangan dengan perjalanan pengelolaan zakat sebelumnya. Penelitian ini berbasis studi literatur dari kajian literatur zakat klasik hingga kontempore, dapat disimpulkan hasil penelitian ini : pertama bahwa UU tersebut merubah struktur LAZ menjadi sub-ordinasi dari pemerintah, sehingga semangat kebersamaan yang ada dalam UU sebelumnya, diubah menjadi semangat sentralisasi, kedua syarat pendirian LAZ pun dirasa semakin sulit. UU baru memerintahkan LAZ yang mayoritas berbentuk yayasan, untuk berubah menjadi organisasi masyarakat dan mendapatkan rekomendasi BAZNAS dan pejabat berwenang. ketiga adanya ancaman sanksi pidana juga hal lain yang menghambat masyarakat sipil dalam mengelola zakat. Posisi amil tradisional dalam UU ini dianggap ilegal. Dan pelakunya terancam pidana kurungan maupun denda.
\end{abstract}

Kata Kunci: Lembaga Zakat, Regulasi, Yayasan,Masyarakat

\section{A. PENDAHULUAN}

Masyarakat sipil (civil society) identik dengan sekumpulan orang di luar negara, yang dapat mengatur dirinya sendiri (Azra, 2003). Terkesan anti tesis dari negara. Namun, hakikatnya ia sebuah jalur untuk mengemukakan pendapat dan menyalurkan aspirasi publik dihadapan negara. Harapan yang ingin dicapai, warga menjadi tidak terasing dari pemerintahan. Lebih dari itu, civil society menjadi wadah untuk menolak tindakan kesewenang-wenangan penguasa (Mujani, $t \mathrm{t}$ ). Gerakan ini secara operasional berwujud organisasi sosial keagamaan, lembaga swadaya masyarakat (LSM), paguyuban, dan sejenisnya.

Sering disebut organisasi sektor ketiga, karena dalam perjalanannya ia bersifat sosial dan non profit. Ciri dan perannya bervariasi, umumnya berawal dari inisiatif masyarakat berlandaskan 
agama atau adat istiadat. Memiliki tujuan pemberdayaan masyarakat melalui advokasi struktural, meningkatkan kemandirian, dan pengentasan kemiskinan. Sisi pendanaan, organisasi ini memiliki mekanisme penggalangan dana sendiri, tidak bergantung sepenuhnya dari subsidi pemerintah. Hal ini yang menjadikannya lebih mandiri, dan bisa terbebas dari konflik kepentingan dengan pihak pemerintah. Keanggotaannya yang berbasis kerelawanan nilai lebih lainnya. Banyak pihak yang ikut bergabung tidak diniatkan mencari keuntungan, tetapi kerelaan untuk sama-sama berkontribusi. Toucqueville menyimpulkan tiga ciri yang mengindikasikan sebuah gerakan civil society; kesukarelaan (voluntary), keswasembadaan (self-generating), dan keswadayaan (self-supporting) De Tocqueville, 1960).

Di Indonesia, entitas masyarakat sipil bergerak pula di bidang filantropi, khususnya zakat. Beroperasi dengan nama Lembaga Amil Zakat (LAZ), ia memiliki akar sejarah kuat dalam perjalanan pengelolaan zakat Indonesia. Jauh sebelum pengesahan UU pertama tentang pengelolaan zakat yaitu UU Nomor 38/1999, LAZ telah eksis membantu pemerintah dalam pengumpulan, pendistribusian, dan pendayagunaan zakat. Pada tahun 1967, Yayasan Baitul Mal Umat Islam Bank BNI (Bamuis BNI) mulai operasional pengumpulan zakat di kalangan internal Bank BNI, untuk kemudian disalurkan kepada masyarakat umum yang membutuhkan (www.bamuisbni.com). Yayasan Dana Sosial Al-Falah (YDSF) contoh lainnya. Didirikan pada tanggal 1 Maret 1987 di Surabaya, kini telah dirasakan manfaatnya di lebih dari 25 propinsi di Indonesia (www.ydsf.org). Kemudian Dompet Dhuafa, lahir pada tanggal 4 September 1994 dimana gerakan awalnya adalah mengundang pembaca harian umum Republika untuk ikut serta dalam program-program kemanusiaan, masih berdiri hingga kini (www.dompetdhuafa.org).

Secara umum, LAZ dilihat dari sisi sejarah pendiriannya dapat dibagi menjadi empat kelompok, yaitu: pertama, lembaga pengelola zakat yang didirikan dengan basis masjid seperti LAZ Al-Azhar Peduli (Masjid Al-Azhar) dan LAZ Dana Peduli Umat-DT (Masjid Daarut Tauhid). Kedua, lembaga pengelola zakat yang berbasis organisasi massa (ormas), seperti LAZ Pusat Zakat Ummat (Ormas Persis), LAZ Nahdlatul Ulama (Ormas NU), dan LAZ Muhammadiyah (Ormas Muhammadiyah). Ketiga, lembaga pengelola zakat yang berbasis perusahaan, seperti LAZ Baitul Maal Muttaqien (PT. Telkom), Baitul Maal Muamalat (Bank Muamalat Indonesia), Baitul Maal BRI (Bank BRI), dan Baitul Maal Pupuk Kujang (PT. Pupuk Kujang Cikampek). Keempat, lembaga 
pengelola zakat berbasis organisasi sosial atau yayasan, seperti LAZ Rumah Zakat Indonesia dan LAZ Dompet Dhuafa, (Syahab, 2014).

Adiwarman menjelaskan (2008) setidaknya ada empat faktor pemicu pendirian LAZ seperti fenomena di atas. Pertama, semangat menyadarkan umat tentang kewajiban zakat. Proses penyadaran ini hakikatnya kewajiban lembaga pemerintah, untuk menyeru bahkan mewajibkan masyarakatnya membayar zakat. Namun kenyataan tidak demikian. Kealpaan posisi pemerintah inilah yang kemudian memicu semangat amil untuk terus mensosialisasikan kewajiban berzakat dengan wadah LAZ. Kedua, semangat melayani secara profesional. Ketiga, semangat berinovasi dan berkreasi dalam membantu mustahik. Terakhir keempat, adanya semangat untuk memberdayakan masyarakat.

Di tengah semangat masyarakat sipil dalam memberdayakan dana zakat, muncul kemudian regulasi yang tercantum dalam Undang-Undang Nomor 23 Tahun 2011. Negara yang dulu menghindar dari tanggung jawab pengelolaan zakat, melalui UU tersebut berusaha untuk turut andil mengelola zakat. Regulasi ini terkesan bertentangan dengan perjalanan pengelolaan zakat sebelumnya. Hal yang menyebabkan reaksi beragam dari LAZ atas pemberlakuan UU ini. Bagaimana pengaruh regulasi ini terhadap LAZ dan juga mengenai penyikapan LAZ dalam menghadapi UU ini, hal yang menarik sebagai objek kajian oleh penulis.

\section{B. Telaah Literatur tentang Pengelolaan Zakat}

Secara historis, pengelolaan zakat dipungut terpusat oleh pemerintah atau lembaga sejenis yang diberi mandat oleh negara. Pada zaman Rasulullah Saw, beliau menempatkan dirinya sebagai amil. Disamping itu Rasulullah Saw juga mengangkat sahabat lainnya sebagai pemungut zakat. Amil-amil yang diangkat Rasulullah tidak hanya bertugas untuk kepentingan pusat, tetapi juga diutus ke tiap daerah. Ibnu Luthaibah misalkan, adalah amil yang mengurus zakat Bani Sulaim. Ali bin Abi Thalib dan Muadz bin Jabal termasuk utusan Rasulullah ke Yaman, yang disamping bertugas menjadi da'i, juga mempunyai tugas khusus sebagai amil zakat. Anas bin Malik diberi mandat juga untuk menarik zakat di Bahrain (Suma, 2006)

Berdasarkan pengalaman tersebut, Qaradawi kemudian berpendapat selayaknya pengelolaan zakat terintegrasi dalam pantauan negara. Beliau beralasan karena zakat bukanlah bentuk kedermawanan pribadi sebagaimana infak dan sedekah yang bersifat sukarela, tetapi zakat adalah kewajiban yang mengikat setiap muslim. Karena sifat wajibnya ini, maka negara lah yang paling berhak sebagai otoritas pengelola zakat. Karena hanya negara yang memiliki wewenang memaksa. Beberapa kelebihan didapat jika urusan zakat diserahkan 
kepada negara, diantaranya adalah lebih terjaminnya kaum fakir atas ketersediaan dana zakat bagi mereka, dan mereka pun lebih terjaga kehormatannya tanpa harus repot meminta-minta kepada muzakki karena ada perantara negara. Berdesak-desakkan dalam penyaluran zakat pun terhindarkan, wewenang dan kapasitas negara lebih memungkinkan dalam mewujudkan penyaluran zakat yang tertib dan aman (Qaradawi, 1973).

Usman Husein berpandangan serupa. Beliau mengemukakan persetujuannya atas pendapat yang mewajibkan negara mengelola negara. Dan hal ini berlandaskan beberapa alasan diantaranya: Pertama, Allah Swt telah mewajibkan negara untuk mengelola zakat. Hal ini tercantum dalam ayat-ayat Alquran, maupun hadis Nabi Muhammad Saw. Adanya perintah "ambillah zakat" dalam dalil-dalil ini bermakna bahwa zakat butuh pengelola resmi. Begitupun adanya kelompok penerima zakat yang dinamakan Amil, ini bukti selanjutnya bahwa zakat harus ada panitia penyelenggaranya. Dan negara lah sebagai institusi terkuat yang berhak menjadi panitia atau pengelola zakat. Kedua, fenomena di mana zakat diserahkan kepada masing-masing individu, maka yang terjadi adalah sedikitnya masyarakat muslim dalam kategori muzakki yang menunaikan kewajiban zakatnya. Hal ini disebabkan naluri alami manusia yang mencintai harta duniawi. Maka di sini kewajiban negara untuk mendorong masyarakatnya membayar zakat (Abdullah, 1989).

Zakat pun di samping bersifat diyani (tuntunan agama) yang ditunjukkan oleh kenyataan bahwa ia merupakan salah satu rukun Islam, zakat pula memiliki sisi qadha'i (implikasi hukum) (Miftah, 2007). Sifat qadha' $i$ ini terlihat pada beberapa hal: Pertama, bahwa zakat bukan bentuk belas kasihan orang kaya terhadap orang miskin. Tetapi ia adalah hak fakir miskin yang ditumpangkan pada harta orang-orang kaya. Kedua, bahwa dalam pelaksanaan zakat melibatkan banyak kepentingan, tidak saja antara muzakki dan mustahiq zakat, tetapi juga antara sesama mustahiq zakat itu sendiri. Oleh karena itu, sebagai hukum yang bersifat qadha' $i$, maka zakat tidak cukup hanya mengandalkan ketaatan pribadipribadi kepada Tuhannya, tetapi ia perlu juga dilaksanakan dengan kekuatan negara.

Namun realita kontemporer menyajikan hal yang berbeda. Mayoritas umat Islam berada di negara sekuler, maka praktik pengelolaan zakat menjadi lebih beragam. Secara umum, kini ada dua bentuk pengelolaan zakat (kahf, 2006). Pertama, sistem pembayaran zakat yang bersifat wajib dan memaksa (obligatory system) seperti di Pakistan, Sudan, Libya, Yaman, Malaysia, dan Arab Saudi. Dalam sistem ini jika terjadi kelalaian, maka wajib zakat akan dihadapkan pada sanksi pelanggaran Undang-Undang. Kedua, sistem pembayaran zakat secara 
sukarela (voluntary system) seperti di Kuwait, Bangladesh, Yordania, Indonesia, Mesir, Afrika Selatan, dan negara-negara dimana muslim adalah minoritas.

Sebuah contoh di Arab Saudi, kewenangan zakat di Saudi langsung dikendalikan oleh mas\}lahłah al-zakah wa al-dakhl (kantor pelayanan zakat dan pajak) di bawah kementerian keuangan. Tidak heran jika warga Saudi mengidentikan zakat sama dengan pajak, karena sistem yang dibangun serupa diantara keduanya. Adapun wilayah penyaluran dan pendayagunaan zakat diberikan kepada departemen sosial dan pekerjaan di bawah kementerian jaminan social (Ridho, 2006).

Contoh lain di Pakistan, negara ini menggunakan pendekatan terpusat dengan membentuk Dewan Zakat Pusat yang memiliki empat level organisasi di bawahnya. Di bawah Dewan Zakat Pusat, diikuti oleh Dewan Zakat Provinsi (satu di setiap provinsi), Dewan Zakat Kabupaten (satu di setiap distrik), Tehsil Zakat (Tehsil adalah subordinat dari Kabupaten) dan Komite Zakat Lokal (satu untuk setiap desa). Pola distribusi zakatnya, 60 persen dari total penerimaan zakat ditransfer ke setiap provinsi. Sisa 40 persen dipertahankan oleh Dewan Zakat Pusat yang kemudian akan disalurkan untuk lembaga-lembaga medis nasional, lembaga pendidikan dan kesejahteraan, dan persiapan dana darurat bencana.Hudayati and Tohirin, 2014)

Malaysia mempunyai cara lain dalam mengelola zakat. Pengelolaan zakat di Malaysia berada di bawah koordinasi Majelis Agama Islam (MAI) yang bertanggung jawab langsung pada Perdana Menteri. Dari MAI ini, didirikanlah lembaga khusus pengelola zakat yang dinamakan Pusat Pungutan Zakat (PPZ). Desain manajemen PPZ menekankan pada profesionalitas dan budaya kerja korporasi. Intinya, PPZ dibentuk menjadi sebuah perusahaan swasta murni yang hanya bertugas menghimpun zakat. Untuk tugas penyaluran dana zakat, MAI telah memiliki Baitul Maal (BM) yang kedudukannya sejajar dengan PPZ (Haji Alias, Syed Omar, dan Ab Rahman,2014).

Adapun di Indonesia, meski masih bersifat sukarela, namun dorongan agar pemerintah mengelola zakat sudah muncul. Hal ini dikarenakan, pelegalan kewajiban zakat secara kenegaraan sangat menunjang kebijakan dan program kesejahteraan masyarakat yang dicanangkan oleh pemerintah. Dengan pengintegralan lembaga zakat ke dalam satu institusi kenegaraan inilah diharapkan mekanisme pengelolaan zakat menjadi lebih efektif. Dalam tulisannya Jamal Doa, (2002) banyak manfaat yang didapat pemerintah Indonesia ketika mengelola zakat, diantaranya:

a. Meningkatkan penerimaan negara dalam APBN, sehingga anggaran pembangunan dapat ditingkatkan. 
b. Meningkatkan jumlah wajib pajak dan jumlah wajib zakat.

c. Wajib zakat dapat diadministrasikan secara akurat dan modern.

d. Optimalisasi pencapaian UUD 1945 Pasal 34 yang berbunyi: "Fakir miskin dan anak terlantar dipelihara oleh negara."

Dalam praktiknya, pengelolaan zakat oleh pemerintah di Indonesia belum mendapatkan pijakan yuridis konstitusi yang jelas. Jika dikaitkan dengan UUD 1945 Pasal 23, yang menyebutkan bahwa pajak dan pungutan lain yang bersifat memaksa untuk keperluan negara diatur dengan Undang-Undang, muncul perdebatan apakah zakat termasuk kategori pungutan memaksa untuk keperluan negara? Adapun jika landasannya adalah UUD 1945 Pasal 34 tentang jaminan sosial bagi seluruh rakyat, fakta yang tercantum dalam UU Sistem Jaminan Sosial Nomor 40/2004 dan turunannya UU Nomor 24/2011, tidak menyebutkan zakat sebagai salah satu komponen jaminan sosial. Yang memungkinkan adalah Pasal 28 dan 29 UUD 1945 tentang kebebasan beragama dan jaminan negara bagi warganya untuk beribadat menurut agama dan kepercayaannya. Implikasinya pengelolaan zakat dikembalikan menjadi hak setiap warga negara atas dasar keyakinan ibadahnya, bukan sentralisasi oleh Negara (susetyo, 2008).

Secara garis besar, pengelolaan zakat yang beragam di Arab Saudi, Pakistan, Malaysia, dan Indonesia menunjukkan karakteristik yang berbeda dalam hal pendekatan yang mereka gunakan. Arab Saudi dan Pakistan cenderung menggunakan pendekatan sentralistik oleh negara. Sedangkan Malaysia menyediakan pembelajaran yang menarik, tersentralisasi di level Negara namun didistribusikan di setiap negara bagian sesuai wewenangnya. Sementara manajemen zakat di Indonesia cenderung mengikuti pendekatan desentralisasi. Masyarakat bebas mengelola dan mendistribusikan zakat tanpa campur tangan negara.

Fenomena perbedaan praktik tersebut di atas, cukup menjelaskan bahwa wewenang pengelolaan zakat menjadi wilayah ijtihad. Masingmasing wilayah, mengambil pendapat yang paling maslahat. Meskipun idealnya terpusat sebagaimana Rasulullah lakukan, namun perbedaan situasi umat Islam di zaman ini membuka pilihan-pilihan lain. Pada akhirnya, pengelolaan zakat berkaitan erat dengan hak yang akan diberikan kepada mustahiq.

\section{Perkembangan Posisi LAZ dalam Pengelolaan Zakat Indonesia}

Penulis berpendapat setidaknya ada tiga fase bagaimana posisi LAZ berkembang dan berkontribusi dalam pengelolaan zakat di Indonesia. Fase pertama dimulai sebelum ada payung hukum setara Undang-Undang. Fase kedua yaitu setelah tahun 1999 di mana UU Zakat pertama berhasil disahkan oleh DPR. Fase ketiga dimulai setelah UU 
Pengeloaan Zakat terbaru pada tahun 2011 disahkan sebagai pengganti UU Pengelolaan Zakat tahun 2009. Detail fase-fase di atas sebagai berikut:

\section{Fase sebelum ada $\mathbf{U U}$}

Indonesia mempunyai pengalaman tersendiri mengelola zakat. Sejak Islam datang ke Indonesia, zakat sudah mulai dikelola dan menjadi salah satu sumber pendanaan penyebaran dakwah Islam. Ketika bangsa ini masih dijajah, bagian sabilillah dalam zakat sudah dijadikan sumber dana perjuangan (Ali, 2006). Urgensi zakat yang terlihat dalam Alquran di mana penyebutan zakat selalu disejajarkan dengan kata shalat, dan ancaman durhaka bagi penentang yang mengingkari kewajiban zakat, sangat dipahami oleh tokoh dan masyarakat Islam pada zaman tersebut. Efeknya, lahir amil-amil individual tradisional skala lokal berbasis masjid dan lingkungan. Bertugas mengumpulkan dana zakat dari lingkungan sekitarnya untuk disalurkan bagi mustahik terdekat.

Di masa kolonial Belanda, pemerintah tidak ikut campur dalam hal pengelolaan zakat mal dan fitrah. Tercantum dalam surat edaran tertanggal 18 Agustus 1866 nomor 216, pemerintah kolonial menghapus semua campur tangan pemerintah daerah atas pungutan sukarela keagamaan. Pemerintah terkesan khawatir akan disalahkan jika mengubah struktur pranata keagamaan di masyarakat. Hal ini bisa jadi disebabkan hasil penelitian Snouck Hurgronje yang melihat bahwa zakat mal, zakat fitrah, sedekah, serta sumbangan-sumbangan keagamaan lainnya sudah mengakar dan melembaga dalam masyarakat ketika itu (Azra, 2006), dan (Fauzia dan Hermawan, 2003).

Perkembangan pengelolaan zakat nasional selanjutnya semakin maju. Setelah fase pengelolaan individu, umat Islam Indonesia mulai menyadari perlunya sebuah lembaga pengelola zakat. Dorongan ini menguat dan direspon pemerintah dengan mengeluarkan Peraturan Menteri Agama Nomor 4 dan 5 tahun 1968, tentang pembentukan Badan Amil Zakat dan Baitul Mal (Balai Harta Kekayaan) di tingkat pusat, propinsi, dan kabupaten/kota. Dimulai dari Permen tersebut, Pemda DKI Jakarta mempelopori pendirian Badan Amil Zakat, Infaq dan Shadaqah (BAZIS) pada tahun 1968 (Ali, 2006). Di berbagai tempat pun akhirnya berdiri badan serupa yang dimotori pejabat daerah setempat dengan dukungan para ulama dan pemimpin Islam.

Pendirian BAZ yang bersifat semi pemerintah, tidak kemudian menyurutkan semangat masyarakat dalam mengelola zakat. Beroperasional dengan nama Lembaga Amil Zakat (LAZ), masyarakat pun ikut serta membantu pemerintah. Pada tahun 1967, Yayasan Baitul Mal Umat Islam Bank BNI (Bamuis BNI) mulai beroperasi. Yayasan 
Dana Sosial Al-Falah (YDSF) berdiri selanjutnya di tahun 1987. Dan masih banyak LAZ lainnya terus berdiri hingga kini.

\section{Fase pasca pengesahan UU 38/1999.}

UU pertama tentang pengelolaan zakat lahir, yaitu UndangUndang Nomor 38 Tahun 1999. Dalam UU tersebut eksistensi LAZ sebagai institusi pengelola zakat yang sepenuhnya dibentuk atas prakarsa masyarakat diakui sebagai lembaga yang legal konstitusional. Efek positif lainnya dari UU ini, Muhtar Sadili mengungkapkan, semenjak lahir Pasal 6 dalam UU 38/1999, jumlah dan terobosan program LAZ terus meningkat seiring kemajuan manajemen zakat yang dirintis oleh para amil profesional. Ada Dompet Dhuafa Republika yang hadir dengan kepedulian media atas realitas kemiskinan, PKPU (Pos Keadilan Peduli Umat) yang lahir karena empati bencana alam, YDSF Surabaya lewat spirit komunalitas Masjid Al Falah-nya (Sadili, 2007).

Secara umum, ketentuan-ketentuan yang tertuang dalam UU Nomor 38/1999, membawa dampak positif bagi perkembangan pengelolaan zakat nasional. Antara lain terlihat bagaimana operasional OPZ (Organisasi Pengelola Zakat) menjadi legal di bawah payung hukum yang sah. Hal ini termasuk bentuk perlindungan bagi warganegara dalam melaksanakan ibadah sesuai ajaran agamanya masing-masing. UU ini juga telah menambah kesadaran masyarakat untuk menunaikan zakat melalui lembaga resmi. Tidak perlu lagi mengumpulkan mustahik di satu tempat, yang terkadang berakhir ricuh dan menyebabkan korban jiwa.

Dengan hadirnya UU Nomor 38/1999, sisi penghimpunan dana zakat mengalami peningkatan. Dalam laporan data penghimpunan zakat nasional tahun 2010 yang dicatat oleh BAZNAS, perolehan zakat pada tahun 2010 ada di angka Rp. 1,5 triliun. Dari total tersebut, 42 persen berasal dari penghimpunan LAZ. Lebih detail, bisa dilihat dalam tabel berikut:

Tabel 1 Data Penghimpunan Zakat Nasional 2010

\begin{tabular}{clcc}
\hline No & Organisasi Pengelola Zakat & $\begin{array}{c}\text { Jumlah } \\
\text { Organis } \\
\text { asi }\end{array}$ & $\begin{array}{c}\text { Penghimpunan } \\
\text { (Rp.) }\end{array}$ \\
\hline $\mathbf{1}$ & $\begin{array}{l}\text { Badan Amil Zakat Nasional } \\
\text { (BAZNAS) }\end{array}$ & 1 & 33.125 .920 .075 \\
$\mathbf{2}$ & $\begin{array}{l}\text { Badan Amil Zakat Daerah } \\
\text { (BAZDA) Provinsi }\end{array}$ & 33 & 306.512 .258 .082 \\
$\mathbf{3}$ & $\begin{array}{l}\text { Badan Amil Zakat Daerah } \\
\text { (BAZDA) Kabupaten/Kota }\end{array}$ & 447 & 525.608 .580 .693 \\
\hline
\end{tabular}




\begin{tabular}{|c|c|c|c|}
\hline 4 & $\begin{array}{l}\text { Lembaga Amil Zakat } \\
\text { Nasional \& Daerah }\end{array}$ & 40 & 634.917 .482 .126 \\
\hline & Total Pengh & & 1.500 .164 .240 .975 \\
\hline
\end{tabular}

Sumber :Laporan Laporan BAZNAS 2010

Di fase ini pula berbagai kajian tentang zakat di tanah air mulai semarak. Zakat mulai dipandang tidak hanya sekedar ibadah mahdhah, ${ }^{1}$ dimana niat menjadi prasyarat dan dihitung sebagai pelaksanaan perintah Allah Swt. Tetapi zakat juga memiliki dimensi sosial dan dimensi ekonomi. Dimensi sosial tergambar dalam proses saling membantu, silih asah asih dan asuh antara masyarakat yang berkecukupan dengan golongan masyarakat lainnya yang serba kekurangan (Hafidhudin, 2007). Dari dimensi ini, zakat diharapkan mampu mengangkat derajat hidup fakir miskin, membantu pemecahan masalah mustahik lainnya, menghilangkan sifat kikir pemilik harta, dan mempererat tali persaudaraan (Ali, 2006).

Keunggulan zakat pun dikaji dari berbagai sisi. Dalam hal ekonomi, Irfan menyebutkan sekurang-kurangnya ada tiga fungsi zakat dalam dimensi ekonomi, yaitu sebagai alat redistribusi pendapatan dan kekayaan sehingga tidak terjadi kesenjangan sosial yang tajam, juga sebagai stabilisator perekonomian untuk meminimalisir deviasi akibat depresi yang selalu mengancam, dan sebagai instrumen pembangunan dan pemberdayaan masyarakat dimana dana zakat didayagunakan dalam pengembangan sektor riil (Beik, 2005). Keunggulan lainnya, zakat bisa dikategorikan sebagai sistem fiskal pertama di dunia yang memiliki kelengkapan aturan luar biasa, mulai dari subjek zakat, objek harta zakat beserta tarifnya masing-masing, batas kepemilikan minimal tidak terkena zakat (nis\}ab), masa kepemilikan harta (haul), hingga alokasi distribusi dana zakat (SEBI-USAID, 2011). Kajian-kajian inilah secara langsung berpengaruh dalam proses akselerasi pengembangan tata kelola zakat di tanah air.

Di saat yang sama, UU ini membawa sejumlah dampak yang tidak diharapkan sebelumnya. Diantaranya peningkatan jumlah OPZ yang pesat, bermunculan baik di tingkat pusat maupun daerah. Amil-amil tradisional berbasis masjid semakin banyak. Hal ini berpotensi menimbulkan masalah dalam hal tata kelola dan kepercayaan masyarakat. Karena tumbuhnya lembaga zakat ini, tanpa didampingi lembaga regulator yang bertugas sebagai pengawas. Sangat mungkin ada, lembaga-lembaga zakat yang hanya bertujuan mengeruk keuntungan dari

Ibadah mahdjah adalah suatu amalan ibadah yang telah ditetapkan cara dan atau kadarnya langsung oleh Allah atau melalui Rasul-Nya. Lihat Quraish Shihab, Wawasan Al-Quran: Tafsir Maudlu'i atas Pelbagai Persoalan Umat (Jakarta: Mizan 1996), 36. 
pengumpulan dana zakat masyarakat, namun dengan transparansi dan akuntabilitas yang rendah. Pengelolaan zakat pun menjadi tidak efisien. Dengan jumlah OPZ yang banyak tanpa diiringi penghimpunan dana yang maksimal, rasio biaya operasional terhadap total penghimpunan dana zakat akan semakin rendah (IMZ, 2010).

Lemahnya relasi antara zakat dan pajak termasuk diantara kekurangan UU ini. Pegiat zakat Indonesia memandang zakat penghasilan sebaiknya berfungsi penuh sebagai pengurang pajak (tax credit), tidak hanya sekedar pengurang penghasilan kena pajak (tax deductible). Yang diharapkan dengan adanya insentif menarik seperti ini, mendorong ketaatan zakat dan menurunkan penghindaran zakat masyarakat (LPEM, 2010). Meskipun kemudian terjadi silang pendapat dengan kementerian keuangan. Anggito (2011) justru berpendapat sebaliknya, jika zakat penghasilan sebagai pengurang pajak, hal ini akan berdampak langsung terhadap penurunan penerimaan negara dari sektor pajak. Ditambah lagi tax credit bisa menimbulkan restitusi (pengembalian pajak) yang proses administrasinya cukup rumit dan rawan.

Sebagai wadah koordinasi dan mewujudkan sinergi, pada fase ini terbentuk Forum Zakat (FOZ) yaitu sejenis asosiasi organisasi pengelola zakat di Indonesia (forumzakat.net). FOZ tidak membedakan, baik lembaga tersebut bentukan pemerintah (BAZNAS) atau organisasi sosial yang didirikan masyarakat (LAZ). Jumlah anggota FOZ terus bertambah, menunjukkan secara langsung perhatian masyarakat dalam mengelola zakat semakin tinggi. Dari semula hanya 11 anggota pendiri, jumlah anggota FOZ bertambah menjadi 150 pada tahun 1999, 160 anggota pada tahun 2003 dan 250 anggota pada 2006 (IMZ, 2010).

FOZ berperan aktif dalam memperbaiki kelemahan-kelemahan UU Nomor 39/1999 di atas, dan memperkuat hal-hal positif yang telah berjalan. Dari tahun 2003 FOZ mulai mewacanakan amandemen UU Nomor 38/1999 ini. Secara riil pembahasan mengenai amandemen ini dimulai sejak Musyawarah Nasional FOZ tahun 2003 di Kalimantan Timur yang mengambil tema "Menggagas Amandemen UU No. 38 Tahun 1999 tentang Pengelolaan Zakat: Menuju Optimalisasi Dana Zakat". Usulan revisi kemudian diajukan ke DPR-RI dan masuk program legislasi nasional (prolegnas) 2005-2009 dan menjadi RUU prioritas tahun 2009.

Pihak pemerintah merespon keinginan amandemen UU Zakat, dengan membentuk tim pengkajian efektifitas UU No. 38/1999 melalui Surat Keputusan Menteri Hukum dan HAM Nomor PHN-37.LT.02.01. tertanggal 1 April 2011. Dipimpin oleh Jaih Mubarok, tim ini bertugas mengkaji bagaimana sistem pengelolaan zakat sebelum dan sesudah UU Nomor 38/1999, bagaimana juga efektifitasnya, dan menyusun usulan 
langkah-langkah pembenahan yang harus dilakukan negara dalam rangka perbaikan pengelolaan negara ke depan. Hasilnya, tim merekomendasikan beberapa saran, antara lain membangun regulasi yang berpihak terhadap pembangunan zakat nasional (BPHN-DEPKUMHAM, 2011). Dengan bahasa lain, tim berpendapat UU yang selama ini berjalan, perlu dibenahi dan diamandemen sedemikian rupa agar lebih bermanfaat.

\section{Fase pasca pengesahan UU 23/2011.}

Setelah melalui pembahasan intensif, Dewan Perwakilan Rakyat (DPR) mengesahkan Undang-Undang Nomor 23 Tahun 2011 tentang Pengelolaan Zakat sebagai pengganti UU zakat sebelumnya. UU baru ini disahkan oleh Presiden pada tanggal 25 November 2011 kemudian dicatatkan pada lembaran negara nomor 115 tahun 2011. Dibanding dengan UU Nomor 38/1999, UU baru ini lebih banyak secara kuantitas. UU Nomor 23/2011 terdiri dari 11 bab dan 47 pasal, adapun UU lama hanya terdiri dari 10 bab dan 25 pasal.

Dari sisi konten, muatan inti yang terkandung di dalam UU baru ini, Ahmad Juwaini (2012) menyimpulkan dalam beberapa poin yaitu:

a. Pengelolaan zakat menjadi wewenang negara. Adapun masyarakat diperkenankan ikut serta mengelola dengan seizin negara.

b. Pengelolaan zakat dilaksanakan oleh BAZNAS yang beroperasi dari tingkat pusat hingga kabupaten/kota secara hirarkis.

c. Anggota BAZNAS berjumlah sebelas orang yang terdiri dari delapan orang perwakilan masyarakat dan tiga orang perwakilan pemerintah. Perwakilan masyarakat terdiri dari ulama, tenaga profesional, dan tokoh masyarakat. Sedangkan perwakilan pemerintah dari unsur kementerian terkait.

d. LAZ berperan membantu BAZNAS dalam pengelolaan zakat (untuk selanjutnya LAZ dapat membentuk perwakilan)

UU Nomor 23/2011 merupakan langkah strategis selanjutnya menuju sinergi pengelolaan zakat, antara pemerintah dan masyarakat. Dalam konteks Indonesia, keberadaan lembaga zakat bentukan masyarakat memiliki andil yang besar dalam mendorong lahirnya institusi zakat yang amanah, kredibel dan profesional. Karena itu dalam UU baru, keberadaan dan operasionalisasi LAZ dijamin dan diakui legalitasnya oleh UU. Ini adalah penguatan eksistensi LAZ dan sejak saat ini LAZ dianggap sebagai bagian dari kekuasaan. LAZ adalah rekan pemerintah dalam mengelola zakat tanah air. Hal ini secara langsung menghilangkan dikotomi pemerintah dan masyarakat dalam pengelolaan zakat (BEik, 2011). 
Pendapat lain dikemukakan oleh Yusuf Wibisono (2011). Dia dengan tegas menganggap pengesahan UU Nomor 23/2011 ini sebagai langkah mundur bagi dunia zakat nasional. Sebagai amandemen UU sebelumnya, UU baru ini seharusnya bisa memberi perlindungan kepada pegiat zakat, memfasilitasi sektor filantropi Islam bagi kepentingan nasional, dan memberikan insentif menarik bagi perkembangan zakat nasional. Namun, yang terjadi sebaliknya. UU Nomor 23/2011 secara langsung membunuh LAZ dengan persyaratan pendirian yang ketat, dan memarginalkan partisipasi masyarakat sipil dalam mengembangkan zakat di mana LAZ hanya diposisikan sebagai pembantu BAZ.

Mayoritas LAZ berpandangan tidak jauh berbeda. Melalui perkumpulan baru yang dinamakan Koalisi Masyarakat Zakat Indonesia (KOMAZ), mereka menggarisbawahi kerugian-kerugian konstitusional akibat disahkannya UU Nomor 23/2011. Diantaranya, tidak terfasilitasinya kebebasan beragama dan pelaksanaan ibadah warga negara dalam menunaikan zakat. Hal ini dikarenakan adanya monopoli pengelolaan zakat dan pemberlakuan syarat tidak rasional ketika mendirikan LAZ. Adanya ancaman kriminalisasi bagi pengelola zakat pun dianggap sebagai tindakan represif, mirip era kolonial Belanda dengan Ordonasi Sekolah Liar dan Ordonasi Guru nya yang bertujuan mengebiri perkembangan pendidikan Islam kala itu (susetyo dkk, 2013).

Sebaliknya, Didin Hafidhuddin menengahi dan menjelaskan bahwa UU ini sama sekali tidak menghilangkan LAZ yang dikelola masyarakat dan juga tidak mematikan kedermawanan sosial. Ruh UU Nomor 23/2011 adalah untuk membuat pengelolaan zakat lebih tertib dan terorganisir dengan baik (Hafidhudin, 2011). Maka tak heran jika mayoritas pasal yang ada membahas tentang BAZ, LAZ, berikut persyaratan dan posisi masing-masing.

Perdebatan terus mengemuka dan berakhir di meja Mahkamah Konstitusi. Dengan nomor perkara 86/PUU-X/2012, Koalisi Masyarakat Zakat Indonesia (KOMAZ) melayangkan gugatan terhadap UU Nomor 23/2011 tentang Pengelolaan Zakat ini. KOMAZ yang diantara anggotanya terdiri dari Yayasan Dompet Dhuafa, Yayasan Dana Sosial Alfalah Malang, Yayasan Yatim Mandiri, Yayasan Rumah Zakat Indonesia, dan lain-lain, melayangkan pengujian tersebut berlandaskan kerugian konstitusional yang dialami pemohon.

\section{Pengaruh UU Nomor 23/2011 terhadap Posisi LAZ}

Pada awalnya, UU Nomor 23/2011 diharapkan bisa menutup kelemahan yang dimiliki UU sebelumnya. Beberapa kelemahan UU Nomor 38/1999 diantaranya, ketiadaan pihak yang berperan sebagai regulator dan koordinator kegiatan zakat nasional. Namun kenyataannya 
persoalan UU baru ini cukup pelik. Posisi LAZ dalam UU ini terkesan dimarginalkan. Negara pun menjadi superioritas dalam pengelolaan zakat (Wibisono, 2012). Secara garis besar, UU Nomor 23/2011 berpengaruh pada LAZ dalam hal sistem koordinasi di mana BAZNAS berfungsi sentral sebagai regulator dan operator zakat. Pendirian LAZ juga dipersulit dengan syarat-syarat yang ketat. Dan amil tradisional yang selama ini membantu masyarakat dengan pengelolaan zakatnya, terancam dengan pidana kurungan dan denda. Penjelasan lebih detail sebagai berikut:

\section{Sentralisasi Zakat}

Tercantum dalam Pasal 5, Pasal 6, dan Pasal 7 dalam UndangUndang Pengelolaan Zakat 2011 ini, semangat untuk melakukan sentralisasi pengelolaan zakat nasional sepenuhnya di tangan pemerintah, yaitu melalui keberadaan BAZNAS (Badan Amil Zakat Nasional) dari tingkat nasional, provinsi dan kabupaten/kota. BAZNAS diberikan wewenang powerfull dalam pengumpulan, pendistribusian, dan pendayagunaan zakat. Lembaga ini melaksanakan sekaligus fungsi perencanaan, pelaksanaan, pengendalian, pelaporan dan pertanggungjawaban. BAZNAS pun diposisikan sebagai lembaga pemerintah non-struktural yang bersifat mandiri dan bertanggung-jawab kepada Presiden melalui Menteri Agama.

Adapun LAZ sebagai pengelola zakat yang dibentuk masyarakat sipil, dalam UU Nomor 23/2011 Pasal 17 ini ditempatkan sebagai subordinasi dari BAZNAS dengan secara eksplisit menyatakan eksistensi pendirian Lembaga Amil Zakat hanya sekedar membantu BAZNAS.

Dibandingkan dengan UU Pengelolaan Zakat sebelumnya, yaitu UU Nomor 38/1999, jelas nyata perbedaan mengenai posisi LAZ. Hal ini merubah secara mendasar sistem pengelolaan zakat sebelumnya, di mana pengelolaan zakat nasional dilakukan oleh pemerintah (BAZ) dan masyarakat sipil (Lembaga Amil Zakat) secara sejajar dan berdampingan. Dalam UU Nomor 38/1999, khususnya dalam Pasal 5, Pasal 7, dan Pasal 8 , jelas terlihat adanya semangat kebersamaan, yang bertujuan untuk meningkatkan peranan pranata keagamaan, tanpa membedakan antara lembaga pemerintah dan masyarakat sipil.

Oleh sebab itu, muncul penolakan dari LAZ mengenai UU baru tentang pengelolaan zakat ini. LAZ berpendapat sentralisasi pengelolaan zakat oleh pemerintah, bersifat ahistoris dan mengingkari peran masyarakat sipil dalam konteks Indonesia kontemporer yang demokratis (Susetyo dkk, 2013) dan (www.mahkamahkonstitusi.go.id). Kinerja zakat nasional justru mengalami kebangkitan di tangan Lembaga Amil Zakat bentukan masyarakat sipil. Data statistik mengenai proporsi penerimaan 
ZISWAF pada tahun 2010 (lihat tabel 1), diperoleh fakta bahwa LAZ dengan jumlah 40 organisasi, berhasil mengumpulkan dana sebesar $42 \%$ (sekitar 635 milyar) dari total pengumpulan nasional (BAZNAZ, 2010). Hal ini menunjukkan bahwa kinerja Lembaga Amil Zakat sangat signifikan dalam pengumpulan dana ZISWAF di Indonesia.

Ide sentralisasi pun diyakini tidak selamanya membawa efek positif. Banyak kelemahan ditemukan dalam proses sentralisasi, diantaranya adalah adanya kemungkinan penurunan kecepatan dalam pengambilan keputusan dan kualitas keputusan. Sentralisasi juga bisa menyebabkan demotivasi dan disinsentif bagi pengembangan unit organisasi (dalam hal ini LAZ). Unit organisasi terancam sulit mengembangkan potensi dirinya karena tidak ada wahana dan dominasi pimpinan yang terlalu tinggi. Tidak heran jika permasalahan organisasi akan semakin rumit karena banyaknya masalah pada level unit organisasi yang di bawah semua dibawa ke level tertinggi (Sudarwati dan Waras S, 2011).

Pemerintah sebagai pihak yang meratifikasi UU baru ini mencoba menjawab masalah di atas. Menurut Pemerintah UU Nomor 23/2011 tentang Pengelolaan Zakat ini, tidak mengarah pada sentralisasi pengelolaan zakat dan tidak ada dominasi BAZNAS terhadap LAZ. Undang-Undang ini bertujuan untuk mensinergikan peran masyarakat dan negara dalam pengelolaan zakat. Hal yang dipermasalahkan dalam Pasal 17 tidak dimaksudkan untuk melemahkan atau mengubah sistem zakat yang telah ada sebelumnya. Kata "membantu" dalam pasal tersebut dimaksudkan untuk membantu sistem pengumpulan, pengelolaan, pendistribusian, dan pendayagunaan zakat dan bukan dimaksudkan sebagai subordinasi dalam arti kelembagaan. Namun demikian LAZ berkewajiban untuk memberikan pelaporan terhadap pelaksanaan kegiatannya kepada BAZNAS sebagaimana diatur dalam Pasal 19 UU Pengelolaan Zakat.

Pemerintah bermaksud dengan UU ini mengintegrasikan seluruh kekuatan dalam pengelolaan zakat di Indonesia. Kata "integrasi" adalah asas yang melandasi kegiatan pengelolaan zakat di Indonesia. Dan integrasi jelas berbeda dengan sentralisasi. Melalui integrasi diharapkan potensi dan realisasi pengumpulan zakat dari seluruh daerah serta manfaat zakat untuk pengentasan kemiskinan, akan lebih terukur berdasarkan data dan merata. Adapun mengenai posisi BAZNAS sebagai koordinator, hal ini merupakan konsekuensi logis dari integrasi (Nasar, 2011). Koordinator inilah yang nantinya memimpin jalannya proses integrasi dan sinergi, baik dari sisi manajemen maupun dari sisi kesesuaian syariah (shariah compliance). 
Mahkamah Konstitusi menguatkan pendapat pemerintah seperti di atas. Mahkamah berpendapat negara dalam konsepsi religious welfare state bukan hanya berhak, melainkan memiliki kewajiban, untuk menciptakan dan memajukan kesejahteraan umum yang bersifat lahir dan batin. Campur tangan negara terhadap pengupayaan kesejahteraan umum mutlak harus dilakukan, termasuk dalam hal pengelolaan zakat Makhkamah Konstitusi, 2013). Kemudian mengenai pembentukan lembaga pengelola zakat, infak, dan sedekah yang bersifat nasional oleh Pemerintah (BAZNAS), Mahkamah berpendapat hal tersebut tidak menghalangi hak warga negara untuk, antara lain, membangun masyarakat, bangsa, dan negara; meyakini kepercayaan; bebas dalam berserikat dan berkumpul; maupun mengembangkan dirinya secara utuh sebagai manusia yang bermartabat. Pembentukan suatu lembaga pengelola zakat oleh Pemerintah dimaknai Mahkamah dalam konteks memperkuat dan mensinergikan pelayanan zakat, infak, dan sedekah yang telah dilakukan oleh lembaga pengelola zakat bentukan masyarakat maupun oleh amil perorangan.

\section{Kesulitan dalam Pendirian LAZ}

Dalam UU Nomor 23/2011 ini, Lembaga Amil Zakat mendapat restriksi persyaratan pendirian yang sangat ketat. Dalam Pasal 18 disebutkan pembentukan LAZ wajib mendapat izin Menteri atau pejabat yang ditunjuk oleh Menteri. Yang lebih sulit lagi, izin tersebut hanya akan diberikan jika LAZ dapat memenuhi persyaratan paling sedikit sebagai berikut:

a. Terdaftar sebagai organisasi kemasyarakatan Islam yang mengelola bidang pendidikan, dakwah, dan sosial.

b. Berbentuk lembaga berbadan hukum.

c. Mendapat rekomendasi dari BAZNAS.

d. Memiliki pengawas syariat.

e. Memiliki kemampuan teknis, administratif, dan keuangan untuk melaksanakan kegiatannya.

f. Bersifat nirlaba.

g. Memiliki program untuk mendayagunakan zakat bagi kesejahteraan umat.

h. Bersedia diaudit syariat dan keuangan secara berkala.

Keberatan dilayangkan oleh pihak LAZ, khususnya terhadap klausul dalam ayat (2) huruf a yang mewajibkan LAZ terdaftar sebagai organisasi kemasyarakatan Islam. Karena pada kenyataannya hampir seluruh Lembaga Amil Zakat berbadan hukum Yayasan, yang berarti 
secara hukum tidak dapat didaftarkan sebagai Ormas. ${ }^{2}$ Dalam UU yang telah disahkan, tidak terdapat pula payung hukum untuk mengubah badan hukum Yayasan menjadi badan hukum lain. Satu-satunya solusi yang mungkin dilakukan akibat syarat tersebut adalah Lembaga Amil Zakat yang berbadan hukum Yayasan membubarkan diri (berhenti mengelola dana zakat). Kemudian memulai lagi kegiatan dari awal dengan membentuk badan hukum perkumpulan (ormas). Fakta historis menguatkan argumentasi di atas. Kebangkitan zakat nasional di tangan masyarakat sipil, dirintis dan dipelopori LAZ yang tidak berafiliasi dengan ormas Islam.

Birokratisasi pun terasa dalam penentuan syarat pendirian LAZ ini. Adanya syarat rekomendasi BAZNAS dan struktur BAZDA regional di bawahnya, seolah tidak memahami praktik pengelolaan zakat di lapangan. Juperta Panji selaku pengelola LAZ di Lampung menyatakan, bagaimana mungkin mendapatkan izin dari BAZDA, karena BAZDA Lampung sendiri tidak ada (tidak aktif). Hal yang mustahil jika lembaga yang tidak aktif diberikan wewenang untuk mengaktifkan lembaga lain (Susetyo dkk, 2013).

BAZNAS mencoba menjelaskan maksud Pasal 18 mengenai persyaratan pendirian LAZ. Dalam kesaksian di Mahkamah Konstitusi (2012) menyatakan bahwa persyaratan-persyaratan ini dimaksudkan untuk mencegah penyalahgunaan dana zakat untuk kepentingan individu atau kelompok yang bertentangan dengan tujuan zakat itu sendiri. Hal ini akan berdampak positif juga pada LAZ dengan bertambahnya akuntabilitas sebuah lembaga, bertambah pula kepercayaan masyarakat.

Pada akhirnya, Mahkamah Konstitusi menerima keberatan yang diajukan oleh LAZ mengenai Pasal 18 ini. Mahkamah berpendapat syarat pemberian izin pembentukan LAZ sebagaimana dimaksud oleh Pasal 18 ayat (2) huruf a dan huruf b UU 23/2011 tidak harus berbentuk ormas. Karena UUD 1945 tidak membatasi siapa yang berhak melakukan pengumpulan, pendistribusian, dan pendayagunaan zakat.

Mahkamah pun berpendapat Pasal 18 ayat (2) huruf a dan huruf $b$ UU 23/2011 yang mensyaratkan bahwa LAZ harus terdaftar sebagai organisasi kemasyarakatan Islam atau berbentuk lembaga berbadan hukum mengakibatkan ketidakadilan sebab menafikan keberadaan lembaga atau perorangan yang selama ini telah bertindak sebagai amil zakat. Atas pertimbangan tersebut, Mahkamah menyatakan bahwa ketentuan Pasal 18 ayat (2) huruf a dan huruf b UU 23/2011, tidak dapat dimaknai sebagai syarat kumulatif, melainkan kedua syarat dalam dua

${ }^{2}$ Undang-Undang Yayasan Nomor 16 Tahun 2001 secara implisit menyatakan bahwa Yayasan tidak memiliki Anggota. Sedangkan Ormas secara eksplisit dinyatakan dalam UU Ormas Nomor 8 Tahun 1985 sebagai entitas yang berbasis keanggotaan. 
poin (huruf) a dan b tersebut harus dibaca dalam satu kesatuan yang merupakan pilihan atau alternatif. Dengan perkataan lain, lembaga yang berkeinginan menjadi LAZ boleh memilih salah satu status, yaitu apakah berbentuk a) organisasi kemasyarakatan Islam; atau b) lembaga berbadan hukum.

\section{Ancaman Kriminalisasi LAZ}

Dalam Pasal 38 dan Pasal 41 UU Nomor 23 Tahun 2011 ini, dianggap memberikan dasar hukum praktik kriminalisasi terhadap para amil zakat yang tidak memiliki ijin pejabat yang berwenang. Pasal-pasal tersebut menyebutkan bahwa setiap orang dilarang dengan sengaja bertindak selaku amil zakat melakukan pengumpulan, pendistribusian, atau pendayagunaan zakat tanpa izin pejabat yang berwenang. Bagi warga negara yang dengan sengaja dan melawan hukum melanggar ketentuan tersebut, akan dipidana dengan pidana kurungan paling lama satu tahun dan atau pidana denda paling banyak Rp. 50.000.000,00 (lima puluh juta rupiah).

Berdasarkan UU di atas, masyarakat sipil tidak bebas lagi mengelola zakat. Semua amil zakat yang beroperasi tanpa izin meski memiliki kredibilitas tinggi dan karenanya, mendapat kepercayaan tinggi dari masyarakat, akan dikriminalkan apakah dikenakan denda ataupun kurungan. Padahal praktik selama ini, terjadi pengelolaan zakat di masjidmasjid, pondok pesantren, sekolah-sekolah, madrasah-madrasah, bahkan kiai secara perseorangan, rutin mengumpulkan zakat untuk disalurkan kepada lingkungan terdekat. Di lihat dari sisi hukum, kriteria pemidanaan yang harus memperhatikan tujuannya, adanya unsur victimizing, prinsip biaya dan hasil, dan dukungan masyarakat, tidak terpenuhi dalam mengkriminalisasi LAZ seperti yang tercantum dalam Pasal 41 di atas. Maka pendekatan insentif lebih layak dilakukan daripada pendekatan sanksi (Utami dan Nugraheni, 2013). Kekhawatiran atas ancaman ini diungkap oleh Ali Yasin selaku pengelola LAZ di masjid Salahuddin, Sidoarjo. Ali menyatakan bagaimana dirinya merasa tidak nyaman dalam mengelola zakat karena dianggap ilegal karena tidak berizin. Membentuk Unit Pengumpul Zakat (UPZ) sebagaimana diamanahkan UU juga tidak solutif. Karena mayoritas muzakki ingin melihat langsung bagaimana zakat yang mereka bayar diberdayakan dan didayagunakan. Sedangkan UPZ hanya berfungsi sebagai pengumpul, bukan penyalur Susetyo dkk, 2013).

Namun pemerintah memiliki pandangan tersendiri. UndangUndang Nomor 23 Tahun 2011 tidak dimaksudkan untuk mengkriminalisasi amil zakat tradisional, seperti di masjid-masjid dan tempat lainnya, karena masih tetap bisa mengelola zakat dengan status 
sebagai UPZ di bawah koordinasi BAZNAS. Jika tidak ada ketentuan hukum seperti di atas, maka dikhawatirkan terjadi hal berikut (Mahkamah konstitusi.go.id, 2013):

a. Potensi ZISWAF (zakat, infaq, shadaqoh, dan wakaf) yang jumlahnya mencapai triliunan rupiah $^{3}$ tidak dapat dikelola secara baik, akuntabel dan transparansi.

b. Dana ZISWAF terancam dipergunakan sesuai dengan selera pengurus LAZ itu sendiri.

c. Semakin banyak muncul LAZ yang tidak menerapkan prinsipprinsip pengeloaan dana ZISWAF sesuai UU. Karena setiap orang siapa saja bisa berperan sebagai LAZ.

Sebagai solusinya, tercantum dalam ketentuan peralihan di Pasal 43, di mana masyarakat diberikan waktu selama 5 tahun untuk menyesuaikan dengan Undang-Undang. Harapan pemerintah, dalam waktu yang cukup tersebut Lembaga Amil Zakat yang beroperasi tanpa izin meski memiliki kredibilitas tinggi, bisa mengurus perizinannya guna terciptanya perlindungan dan kepastian hukum terhadap pihak-pihak yang terkait dengan pengelolaan zakat.

Dalam menafsirkan Pasal ini, Mahkamah Konstitusi berpendapat bahwa frasa "setiap orang" pada Pasal 38 UU 23/2011 terlalu luas, sehingga berpotensi mengkriminalisasi pelaksanaan zakat yang selama ini telah berjalan, yaitu pelaksanaan zakat yang dilakukan oleh perkumpulan, perseorangan, takmir/pengurus mesjid, dan lain sebagainya. Dan kenyataannya pula masih banyak daerah yang belum terjangkau oleh BAZNAS, BAZDA, ataupun juga LAZ. Belum tersedianya BAZ dan LAZ dalam penyaluran zakat dimaksud, sementara pada saat yang sama amil zakat yang tidak memiliki izin dari pejabat berwenang telah dilarang memberikan pelayanan, tentu mengakibatkan terhalanginya hak warga negara untuk membayarkan zakat sebagai bagian dari ibadah mereka.

Dengan pertimbangan di atas, Mahkamah memutuskan pengecualian dari Pasal 38 ini bagi perkumpulan orang, perseorangan tokoh umat Islam (alim ulama), atau pengurus/takmir masjid/musholla di suatu komunitas dan wilayah yang belum terjangkau oleh BAZ dan LAZ, dan telah memberitahukan kegiatan pengelolaan zakat dimaksud kepada pejabat yang berwenang. Bagi mereka diberikan kebebasan untuk

\footnotetext{
${ }^{3}$ Dalam studi yang dilakukan Fakultas Ekonomi dan Manajemen Institut Pertanian Bogor (FEM-IPB) bekerjasama dengan Islamic Research and Training Institute (IRTI), disebutkan bahwa potensi zakat Indonesia mencapai Rp. 217 triliun. Lihat Irfan Syauqi Beik, dkk., Economic Estimation and Determinations of Zakat Potential in Indonesia (Jeddah: IRTI, 2012), 14-19. Studi lain yang juga meneliti tentang potensi zakat dilakukan oleh Sekolah Tinggi Ekonomi Islam SEBI (STEI SEBI) bekerja sama dengan United States Agency International Development (USAID) pada tahun 2011. Potensi zakat Indonesia dalam penelitian ini menunjukkan angka Rp. 106,6 triliun. Lihat SEBI-USAID, Laporan Penelitian: Kajian Pengembangan Potensi Zakat di Indonesia (Jakarta: SEBI, 2011), 10.
} 
mengelola zakat, sepanjang diketahui pejabat berwenang Mahkamah konstitusi.go.id, 2013).

\section{E. Penyikapan LAZ terhadap UU Nomor 23/2011}

Pasca disahkannya UU Nomor 23/2011 beragam sikap yang dilakukan oleh LAZ. Secara umum mayoritas LAZ keberatan bahkan terkesan menolak terhadap Undang-Undang ini. Hal tersebut tergambar dari beragam komentar tiap-tiap pimpinan LAZ di media, maupun gerakan komunal beberapa LAZ untuk berkumpul dan mengajukan judicial review kepada Mahkamah Konstitusi. Terbentuklah Koalisi Masyarakat Zakat (KOMAZ) yang dimotori LAZ-LAZ kategori besar seperti Dompet Dhuafa, Yayasan Dana Sosial Al-Falah (YDSF), Yayasan Yatim Mandiri, dan Rumah Zakat Indonesia (Susetyo dkk, 2013). KOMAZ inilah yang kemudian mengajak beberapa amil perseorangan untuk secara resmi mendaftarkan gugatan dan mereka sebut dengan istilah ikhtiar tabayyun konstitusi.

Adapun secara kelembagaan, beberapa LAZ mentransformasi dirinya agar bisa lebih fleksibel dalam menghadapi UU baru. Dompet Dhuafa misalkan, yang memutuskan untuk memisahkan keuangan yang ada di Direktorat Bisnis, Fundrising, dan Program. Hal ini membuat Dompet Dhuafa berubah menjadi sebuah holding company yang membawahi dua sub organisasi di bawahnya, yaitu LAZ Dompet Dhuafa dan Dompet Dhuafa Corpora. Kelembagaan DD Corpora ini ditetapkan bersifat mandiri, berbadan hukum perseroan, dengan kepemilikan saham utama pada Yayasan Dompet Dhuafa Republika (www.dompetdhuafa.org). DD Corpora ini bergerak di bidang bisnis sosial, memfasilitasi dana CSR dari berbagai perusahaan, untuk dikelola dan diberdayakan dengan baik, yang tentunya segala keuntungan yang didapat diperuntukan untuk mendukung kegiatan Yayasan Dompet Dhuafa Republika.

Pos Keadilan Peduli Umat (PKPU) memilih alternatif lain. Dengan berbekal pengalaman bergerak dalam aktifitas sosial, PKPU kemudian mendaftarkan diri sebagai Organisasi Sosial Nasional (Orsosnas). Disetujui oleh Menteri Sosial, menjadikan PKPU sebagai wadah masyarakat mitra pemerintah dalam mewujudkan kesejahteraan sosial di bawah koordinasi Direktur Jenderal Pemberdayaan Sosial di Kementerian Sosial RI (pkpu.or.id). Posisi seperti di atas, menjadikan PKPU tidak kaku dalam mengadaptasi Undang-Undang Pengelolaan Zakat di bawah koordinasi Kementerian Agama RI. Bahkan PKPU masuk dalam daftar Non Government Organization (NGO) di PBB dengan menyandang status sebagai NGO in Special Consultative Status with the Economic and Social Council of the United Nation (pkpu.or.id). 
Hal yang serupa dengan PKPU dilakukan oleh Rumah Zakat Indonesia (RZI). Berkantor pusat di Bandung, RZI tidak mencukupkan diri sebagai LAZ. RZI terdaftar juga di Dinas Sosial Kota Bandung dan mengajukan pengajuan sebagai Organisasi Sosial diajukan juga kepada Dinas Sosial Propinsi Jawa Barat (www.rumahzakat.org). Akhirnya, posisi RZI meskipun pada awalnya sebagai LAZ, memiliki akses dan dilindungi oleh Dinas Sosial setempat sebagai mitra pemerintah.

Langkah berbeda dilakukan oleh LAZ daerah maupun amil tradisional yang terdapat di masjid-masjid. Wildan Humaidi dalam studinya tentang respon Lembaga Pengelola Zakat di Kota Yogyakarta terhadap UU Nomor 23/2011 menyebutkan bahwa LAZ Masjid Syuhada dan Masjid Jogokariyan sebagai representatif amil tradisional cenderung menerima regulasi ini. Meski mereka menyatakan keberatan tentang UU ini, namun mereka tidak mempunyai kekuatan dan keterbatasan sumber daya manusia untuk menolak UU ini (Humaidi, 2012). Dan pada praktiknya, LAZ ini pun tidak bisa menolak jika ada masyarakat yang tetap mempercayakan zakat kepada mereka.

Studi lain mengenai implementasi UU Nomor 23/2011 dilakukan di kota Malang (Rosyidah dan Manzilati, tt). Lazis Sabilillah dan LPP Ziswaf Harapan Umat sebagai sample meragukan UU Nomor 23/2011 dapat dilaksanakan dengan baik. Hal ini disebabkan belum ada sosialisasi menyeluruh dari pemerintah. Secara psikologis, dampak adanya undangundang ini mempengaruhi masyarakat yaitu menjadikan pihak pengelola zakat menjadi resah dan membatasi ruang gerak dari lembaga zakat, akibat adanya berbagai persyaratan dan birokrasi yang menyulitkan dalam UU tersebut. Akan tetapi dalam pelaksanaan pengumpulan, pendayagunaan, dan penyaluran tetap berjalan seperti biasa tanpa terpengaruh dengan UU No.23/20011 tentang pengelolaan zakat.

\section{F. Kesimpulan}

Regulasi baru pengelolaan zakat yang tercantum dalam UU Nomor 23 Tahun 2011, dinilai menghambat gerakan masyarakat sipil (LAZ) dalam mengelola zakat di Indonesia. Hal ini tercermin dalam UU tersebut yang merubah struktur LAZ menjadi sub-ordinasi dari pemerintah. Semangat kebersamaan yang ada dalam UU sebelumnya, diubah menjadi semangat sentralisasi. Syarat pendirian LAZ pun dirasa semakin sulit. UU baru memerintahkan LAZ yang mayoritas berbentuk yayasan, untuk berubah menjadi organisasi masyarakat dan mendapatkan rekomendasi BAZNAS dan pejabat berwenang. Ancaman sanksi pidana juga hal lain yang menghambat masyarakat sipil dalam mengelola zakat. Posisi amil tradisional dalam UU ini dianggap ilegal. Dan pelakunya terancam pidana kurungan maupun denda. 
Penyikapan berbeda dilakukan setiap LAZ terhadap UU ini. LAZLAZ besar berusaha untuk taat kepada hukum meskipun dengan cara yang terkesan mengakali. Adapun LAZ-LAZ kecil dan amil tradisional ternyata tidak terpengaruh dengan regulasi ini. Sosialisasi yang minim menyebabkan masyarakat masih dengan sukarela menitipkan zakat kepada mereka. Fenomena yang kontradiktif sebenarnya dengan peran LAZ selama ini. Kinerja zakat nasional mengalami kebangkitan di tangan LAZ bentukan masyarakat sipil. Hal yang cukup dijadikan alasan bagi pemerintah untuk melindungi dan memberdayakan LAZ, bukan malah mempersulit, seolah ingin mematikan kegiatan positif yang sudah berjalan. Karena pada akhirnya, pengelolaan zakat berkaitan erat dengan hak mustahiq yang harus terdistribusikan dengan baik, amanah, dan profesional.

\section{DAFTAR PUSTAKA}

Abdullah, Muhammad dan Abdul Quddus Suhaib. "The Impact of Zakat on Social life of Moslem Society " dalam Pakistan Journal of Islamic Research. Vol 82011.

Abdullah, Usman Husein. Al-D\}ama>n Al-Ijtima>'iy Al-Isla>miy. Manshurah: Dar al-Wafa, 1989.

Ali, Mohammad Daud. Sistem Ekonomi Islam : Zakat dan Wakaf. Jakarta: UI Press, 2006.

Ali, Nuruddin Mhd. Zakat sebagai Instrumen dalam Kebijakan Fiskal, Jakarta: Raja Grafindo, 2006.

Azra, Azyumardi. "Diskursus Filantropi Islam dan Civil Society," dalam Berderma Untuk Semua, ed. Idris Thaha. Jakarta: PBB UIN Syarif Hidayatullah, 2003.

Azra, Azyumardi. "Filantropi dalam Sejarah Islam di Indonesia," dalam Zakat dan Peran Negara, ed. Noor Aflah. Jakarta: FOZ, 2006.

BAZNAS. Laporan Tahunan BAZNAS 2010. Jakarta: BAZNAS, 2010.

Beik, Irfan Syauqi. Economic Estimation and Determinations of Zakat Potential in Indonesia. Jeddah: IRTI, 2012.

De Tocqueville, Alexis. Democracy in America, New York: The New American Library, 1960.

Doa, Muhammad Djamal. Manfaat Zakat Dikelola Negara. Jakarta: Nuansa Madani, 2002.

Fauzia, Amelia dan Ary Hermawan, "Ketegangan antara Kekuasaan dan Aspek Normatif Filantropi dalam Sejarah Islam di Indonesia," dalam Berderma Untuk Semua, ed. Idris Thaha. Jakarta: PBB UIN Syarif Hidayatullah, 2003.

Hafidhuddin, Didin. Zakat dalam Perekonomian Modern. Jakarta: Gema Insani Press, 2002. 
Idris, Safwan. Gerakan Zakat dalam Pemberdayaan Ekonomi Ummat, Jakarta: Cita Putra Bangsa, 1997.

IMZ. Indonesia Zakat and Development Report 2010; Menggagas Arsitektur Zakat Indonesia. Jakarta: Institut Manajemen Zakat, 2010.

Jahar, Asep Saefuddin. "Zakat Antar Bangsa Muslim: Menimbang Posisi Realistis Pemerintah dan Organisasi Masyarakat Sipil” dalam Zakat \& Empowering. Vol 1, Nomor 4, 2008.

Kahf, Monzer. Applied Institutional Models for Zakah Collection and Distribution in Islamic Countries and Communities, Jeddah: IRTI-IDB, 1995.

Kahf, Monzer. Zakah Management in Some Muslim Society, Jeddah: IRTI-IDB, 2000.

Karim, Adiwarman A. dan A. Azhar Syarief. "Fenomena Unik Di Balik Menjamurnya Lembaga Amil Zakat (LAZ) Di Indonesia" dalam Zakat \& Empowering. Vol 12009.

LPEM FE-UI. Indonesia Economic Outlook 2010. Jakarta: Grasindo, 2009.

Mahkamah Konstitusi, Putusan Nomor 86/PUU-X/2012.

Mahkamah Konstitusi, Risalah Sidang Perkara Nomor 86/PUU-X/2012 tanggal 17 Oktober 2012.

Mas'udi, Masdar F. Menggagas Ulang Zakat sebagai Etika Pajak dan Belanja Negara untuk Rakyat, Jakarta: Mizan, 2005.

Miftah, A.A. Zakat antara Tuntunan Agama dan Tuntunan Hukum. Jambi: Sultan Thaha Press, 2007.

Mujani, Saiful. Muslim Demokrat; Islam, Budaya Demokrasi, dan Partisipasi Politik di Indonesia Pasca Orde Baru, Jakarta: Gramedia, tanpa tahun.

Qarad\}awi, Yusuf. Fiqh al-Zakah. Beirut: Muassasah Risalah, 1973.

Republik Indonesia, Undang-Undang Nomor 17 Tahun 2007 tentang Rencana Pembangunan Jangka Panjang Nasional Tahun 2005-2025.

Republik Indonesia, Undang-Undang Nomor 23 Tahun 2011 tentang Pengelolaan Zakat.

Republik Indonesia, Undang-Undang Nomor 38 Tahun 1999 tentang Pengelolaan Zakat.

Ridlo, M. Taufiq. "Pengelolaan Zakat di Negara-Negara Islam," dalam Zakat dan Peran Negara, ed. Noor Aflah. Jakarta: FOZ, 2006.

Sadeq, Abu Al-Hasan, A Survey of The Institution of Zakah: Issues, Theories, and Administration, Jeddah: IRTI-IDB, 2002.

SEBI-USAID. Laporan Penelitian: Kajian Pengembangan Potensi Zakat di Indonesia. Jakarta: SEBI, 2011.

Shihab, Quraish. Wawasan Al-Quran: Tafsir Maudlu'i atas Pelbagai Persoalan Umat. Jakarta: Mizan 1996. 
Sudarwati, Yuni dan Nindya Waras S. "Konsep Sentralisasi Sistem Pengelolaan Zakat dalam Pemberdayaan Ekonomi Umat." Jurnal Ekonomi dan Kebijakan Publik, Vol. 2, No. 1, Juli 2011.

Sudewo, Eri. Manajemen Zakat; Tinggalkan 15 Tradisi, Terapkan 4 Prinsip Dasar. Jakarta: Institut Manajemen Zakat, 2004.

Suma, Muhammad Amin. "Pengelolaan Zakat Pada Awal Pemerintahan Islam," dalam Zakat dan Peran Negara, ed. Noor Aflah. Jakarta: FOZ, 2006.

Susetyo, Heru. Selamatkan Gerakan Zakat. Jakarta: KOMAZ, 2013. Ulwan, Abdullah Nasih. Ahkam al-Zakah. Kairo: Dar al-Salam, 2007.

Utami, Niken Subekti Budi dan Destri Budi Nugraheni, "Kriminalisasi Pengelolaan Zakat (Tinjauan Ketentuan Pasal 41 UU Nomor 23 Tahun 2011" Yustisia, Edisi 85 Januari-April 2013. 